in its scientific aspect, and pregnant with so many benefits to mankind at large.

He was buried on Saturday, his remains being placed beside those of his wife in the family vault at Tewin; the funeral, in accordance with his own wish, being of the simplest character. In addition to the members of his family and private friends, the funeral was attended by the Secretary and Treasurer of the Royal Society, the Hydrographer to the Admiralty, and representatives of the other Government services with which he had been so long connected.

\section{A MINISTER OF PUBLIC INSTRUCTION}

WE are a longsuffering, patient people. The call of Luther to those around him to educate their children and make men of them, as well as provide them with arms - a call at once answered in Germany -is only just now being answered among ourselves.

One of the most beautiful and one of the most touching sights in London now, and one which in our view is a standing disgrace to the politicians who have held sway during the last hundred years, is the gradual rising above dingy roofs and millions of chimneys of the red brick Board schools. The children in London at all events are now being educated, and our future masters are receiving the first rudiments of their instruction, and this much more on account of the intention of their fathers to have it for them, than on account of any farseeing policy of those who are popularly supposed to look in any and every direction for anything that may conduce to the well-being of our country. We have at last got a public instruction, and it is already in the air thai that instruction will in time be as free as it is now compulsory. It is a heartbreaking thing to look back and think what might have been had these all too recently built schools overtopped the squalid dwellings of the poor a century ago. How much less squalid those dwellings would be now. The monumental and extensive prisons would probably be less occupied in their every cell than they are now, but the well-being of the country, the output of the country would have been greater, and the struggle with penury, and dirt, and crime would have been less.

This is only one aspect of education, but yet it seems that in this country at all events it is the mainspring of public opinion with regard to the general question. The cry-on many grounds the mistaken cry-for technical instruction has grown from the work of the Board schools, it has gone along the same line at a higher level, and it will go on still further. The enormous development of the Government Science and Art Classes will also go on, and to the credit of the late Sir Henry Cole be it said here that he was wiser than the politicians, and his clear sight and singlemindedness influenced the head of the department with which he was connected, so that the quiet, slow work in science and art began in $185 \mathrm{I}$, long before the present notions of the importance of education really began to take root in our land.

Now that compulsory education is in our midst, now that the importance of science and of art to the national industries is universally acknowledged, now that it is recog. nised that the education of our workmen must no longer be so disgracefully neglected as it has been, it is again suggested that there should be a Minister to look after these matters.

Ten years ago, as it was well put, the Kinderpest was the care of the Government side by side with the Rinderpest. Both were practically on the same level, both were acknowledged to be nuisances, both might require a public department to look after them, and then money would have to be spent. This was quite a sufficient argument with "statesmen" to let things go on in the old harum-scarum way ; for the policy of a Government is to keep money in its purse, honestly if it can, but in any case to do so, as if England were a miser, acknowledging no responsibilities, spurning all delight; and wishing to live a sordid life like the burghers, caring only for their dykes and pikes, whom Luther shamed out of their indifference centuries ago.

There has again, this week, been a suggestion made that there should be a Minister of Public Instruction, who should be responsible for the preparedness of the country in this respect, just as the Minister of War is responsible for the preparedness of it in another direction. Sir John Lubbock must be congratulated upon the way in which he brought the motion forward last Friday. It was a mild, pleading story. As long ago as 1856 , he pointed out, the late Lord Derby said :-

"It appeared to him well worthy of consideration whether it would not be well to have a Minister, or the head of a department, who should have no other duties to perform, and who should be, in fact, responsible for the education of the people. ... He had a strong feeling that the institution of a Minister of Instruction was desirable, that the subject should be altogether separated from the Privy Council."

But that did no goot. In 1862 there was another resolution put to the House calling on it to affirm that for the education estimates and for the expenditure of all moneys for the promotion of education, science, and art a Minister of the Crown should be responsible to the House. That also did no good. In 1865 a Select Committee was moved for to inquire into the constitution of the Committee of the Council on Education. It was then urged that education and science and art were beginning to be considered of such importance that-

"The great duty of superintending the various branches connected with the Department of Education should be intrusted to some one responsible Minister, some Minister who should be regarded as a State officer of high authority who should have the sole conduct of that department, and be solely responsible."

And that was shelved.

Nine years later, in 1874 , the same view was urged, and the present Prime Minister then admitted "that there was much to be said in favour of the general principle that the expenditure of money for the promotion of education in science and in art should be placed under the control of a single responsible Minister." It is true he said this, but he supported the previous question, so that again came to nothing.

Now that education and science are the gr at things of the day, not only in this but in all countries, England enjoys the proud preeminence of being the only country -civilised country, we know nothing of Timbuctoo--in which there is not a Minister of Public Instruction. It is lamentable, terrible, to read the debate of last Friday, 
and to see the way in which the question was discuised. Mr. Gladstone was impressed by the condition of the House at nine o'clock, but it does not appear that he was impressed with anything else ; the importance of education, the importance of science, the importance of art, the daily, almost hourly, increasing importance of these things does not seem to have entered into the question. To a large extent it was merely a question of Cabinet convenience and Parliamentary tweedledum and tweedledee. How can there be made room in the Cabinet for a Minister of Public Instruction? Are not the affairs of the Duchy of Lancaster of much greater importance, and would not the recognition of the importance of education make the Cabinet unwieldy and give rise to difficulties in Parliamentary procedure? And then there is the Scotch business that must be looked after first, and so on, and so on. Education is evidently not in the region of practical politics.

Heaven knows changes sufficiently great have been made of late years, and it is not absolutely certain that the fundamental bearings of the nature of the changes to be made have in all cases been fully considered; but it seems as though they are to be most carefully considered before any change is made touching the matter of education.

Still it is acknowledged that the question is, after all, one that deserves the attention of Parliament, but Mr. Gladstone had, as usual, three objections to make. In the first place he expressed very great doubt whether, if he had a plan ready to alter the present arrangement, it would be wise to make any declaration on the subject by way of motion. Secondly, he admitted that there was no plan, and he did not think the time had arrived for one ; and lastly, he considered that the subject ought to be a great deal more examined before the House committed itself to a final opinion whether there should be a plan or not.

With reference to his first objection he stated that the House knew perfectly well that administrative changes are made piecemeal, and must continue to be so; and he remarked that there was a good deal to be said in favour of what was called a patched house, because most of us found it the most comfortable sort of house to live in. A Minister of Public Instruction would be a new patch, and as there is patching going on elsewhere he objects to this ; and so on and so on.

The argument which he used in favour of the second objection was, we imagine, the strongest he could have used against it, namely, that the business of the Council Office in respect to education has been in an almost incessant state of flux and change. Of this there can be no doubt that the flux and change will get more pronounced as time goes on. That is the very reason why everything should be brought to a focus.

We may gather from Mr. Gladstone's speech that the Universities should ever, in his opinion, remain divorced fr $\mathrm{m}$ the general question of education; but if so, what is to become of Prof. Huxley's ladder from the gutter to the university? We think, too, if Mr. Gladstone had been fully informed on the subject he could have urged as an additional objection that a great many questions referring to education are never now touched by the Education Department at all.
Several of the speeches might, if we had more space at our disposal, be noticed at some length. Still, we think it worth while to cull the following from the speech of $\mathrm{Mr}$. Forster, an old Vice-President of the Committee of the Council on Education :-

"The Committee of the Council for Trade, or Agriculture, or Education meant nothing whatever. Persons might imagine that the Privy Council occasionally met for the transaction of business, but they never did so either in England or Ireland. The Minister for Agriculture was the President of the Committee of the Council on Agriculture, but he greatly doubted whether that Committee ever met, or ever would meet. . . The real objection (to Sir John Lubbock's proposal) probably was that it was undesirable to make too much of education, that if we were to have a Minister of Education he might be pushing things on too quickly. . . . There might be a fear that under one Minister too much money would be spent. . . . What was complained of now was that there was no really defined responsibility. The man who moved the estimates and did the work was not the head of a department, and he ought to be. The work was done by a Minister who was controlled by another, and the latter was scarcely seen by the public. He did not see why we should continue that Japanese mode of managing affairs."

It is satisfactory to see that the House of Commons is gradually getting into a better position to discuss such questions as these, but we have felt that the main point is, that the head of the Government does not yet consider that the question of education is one of an importance sufficient to be discussed side by side with what in his opinion is the much larger questions of Parliamentary procedure, and the saving of so many pounds, shillings, and pence. It is true a Select Committee has been agreed to, but we fear that after Mr. Gladstone's speech very little will come of it, as has happened before.

It would be ungraceful not to state that the debate brought out in the clearest possible way the valuable services rendered under great difficulties by the present Vice-President of the Committee of the Council on Education, Mr. Mundella.

But the result remains that we are not to have a Minister of Education. There is agricultural business, including the Rinderpest, and other matters, and these are larger questions than that of national education! Therefore national education must wait. As we said before, we are a longsuffering and patient people. There is, however, little doubt that in some political programme of the future this question will find a place ; equal electoral districts and the payment of members are not the only things to be cared for.

F.R.S.

\section{EVOLUTION AND CREATION}

A Few Words on Evolution and Creation; $A$ Thesis maintaining that the World was not made of Matter by the Development of one Potency, but by that of Innumerable Specific Powers. By Henry S. Boase, M.D., F.R.S., \&c. (London: John Leng and Co., I882.)

Notes on Evolution and Christianity. By J. F. Yorke. (London: Kegan Paul, Trench, and Co., I882)

$7 \mathrm{HE}$ first of these works is, as may be inferred from its title, a most curious production. The chief aim of its author is that of sustaining the Biblical Cosmology against what he regards as the fallacious inroads of the theory of Evolution. In carrying out his design he- 